\title{
THE ROLE OF EMPLOYEE AFFECTIVE DELIVERY AND CUSTOMER PERCEIVED CONTROL IN SERVICE RECOVERY
}

\section{ULOGA ZAPOSLENIKOVA AFEKTIVNOG DJELOVANJA I KORISNIKOVE PERCIPIRANE KONTROLE U OPORAVKU USLUGE}

Market-Tržište

Vol. 30, №. 1, 2018, pp. 7-22

UDK 658.8:331.105.2-057.16:159.937:658.89

DOI http://dx.doi.org/10.22598/mt/2018.30.1.7

Original scientific paper

\section{Zsofia Kenesei ${ }^{a}$, Krisztina Kolos ${ }^{\mathbf{b}}$}

a) Corvinus University Budapest, Faculty of Business Administration, 1093, Budapest, Fővám tér 8., HUNGARY, zsofia.kenesei@ uni-corvinus.hu

b) Corvinus University Budapest, Faculty of Business Administration, 1093, Budapest, Fővám tér 8., HUNGARY, krisztina.kolos@ uni-corvinus.hu

\begin{abstract}
Purpose - The aim of this paper is to assess the impact of two non-cognitive service recovery tactics firms actually use: displaying emotional involvement by the provider of the service recovery and intentionally allowing some perceived control for consumers participating in recovery.
\end{abstract}

Design/Methodology/Approach - The research study used a factorial experiment, testing recovery scenarios in a restaurant setting.

Findings and implications - Research results suggest that employee affect and consumers' perceived control have a positive impact on satisfaction. Our research also shows that organizational actions are never perceived in isolation by consumers; there are rich interactions between different forms of recovery attempts. Results have demonstrated that there are interactions among each combination of compensation, employee affect and perceived control. Implications for managers suggest the use of a portfolio of recovery tactics.

Limitations - The study is based on scenario manipulations that were developed and tested through a multi-step strategy; however, some subjects may per-

\section{Sažetak}

Svrha - Cilj je ovog rada procijeniti utjecaj dviju nekognitivnih taktika oporavka usluge koje poduzeća koriste, a to su utjecaj izražavanja emocionalne uključenosti pružatelja oporavka usluge i namjernog dopuštanja percepcije određene razine kontrole samih korisnika koji sudjeluju u oporavku.

Metodološki pristup - $U$ istraživanju je korišten faktorski eksperimentalni dizajn, testirani su scenariji oporavka usluge u restoranu.

Rezultati i implikacije - Rezultati upućuju na to da afektivno djelovanje zaposlenika i korisnikova percepcija kontrole pozitivno utječu na zadovoljstvo. Naše istraživanje također pokazuje da korisnici nikada ne percipiraju izolirano organizacijske aktivnosti. Postoje brojne interakcije između različitih oblika pokušaja oporavka. Rezultati pokazuju da postoje interakcije između svake kombinacije kompenzacije, afektivnog djelovanja zaposlenika i percipirane kontrole. Implikacije za menadžere upućuju na korištenje portfolia taktika za oporavak usluge.

Ograničenja - Istraživanje se temelji na manipulacijama scenarijima koji su razvijeni i testirani u više koraka, ali 
ceive scenarios as less realistic than real life, in-person interactions. Second, individual differences may exist in susceptibility to emotional contagion. In this study, the focus was on general consumer processes, but individual differences is an area that can be investigated in the future.

Originality - With this study we expand the cognitively-dominated understanding of service recovery through the inclusion of the impact of affective ("employee affective delivery") and conative/behavioral ("customer perceived control") service recovery tactics.

Keywords - service recovery, emotional labor, employee affective delivery, perceived control, justice theory neki ispitanici mogu shvatiti scenarije manje realističnima od stvarnog života i osobnih interakcija. Drugo, mogu postojati individualne razlike $u$ osjetljivosti na emocionalni prijenos. $U$ ovom je istraživanju fokus bio na općim procesima korisnika, a individualne razlike su područje koje se može istražiti u budućnosti.

Doprinos - Na ovaj način proširujemo kognitivno dominirajuće razumijevanje oporavka usluge kroz uključivanje utjecaja afektivne ("zaposlenikovo afektivno djelovanje") i konativne/ponašajuće ("percepcija samokontrole korisnika") taktike oporavka usluge.

Ključne riječi - oporavak usluge, emocionalni napor, zaposlenikova afektivno djelovanje, percipirana kontrola, teorija pravde 


\section{INTRODUCTION}

No service is perfect. Nowadays, this is a widespread belief among academics and practitioners alike. Services failures are often inevitable in the service delivery process but they do not necessarily result in the loss of consumers. With right service recovery, it is possible to regain the trust of consumers or even exceed the pre-failure level of satisfaction, as suggested by the concept of service recovery paradox (Hart, Heskett \& Sasser, 1990).

Our understanding of consumer reactions to firms' service recovery efforts has expanded dramatically in the past decade. Satisfaction with service recovery has emerged as the key dependent variable investigated by literally hundreds of studies because of its central role in the psychological processes of consumers and its predictive power with regard to ultimate dependent variables, such as brand attitudes and purchase intent.

Some recent meta-analyses (Gelbrich \& Roschk, 2011; Orsingher, Valentini \& De Angelis, 2010) have investigated the antecedents and consequences of consumer satisfaction with service recovery. These studies indicate that the area is reaching maturity and solidification. The most commonly utilized theoretical tool to model consumer satisfaction with recovery is the justice theory (Maxham \& Netemeyer, 2002; McCollough, Berry \& Yadav, 2000; Smith, Bolton \& Wagner, 1999; Tax, Brown \& Chandrashekaran, 1998). The theory, which has its roots in social exchange and equity theories (Homans, 1961; Walster, Bershcheid \& Walster, 1978), suggests that consumers go through a cognitive appraisal process after/during the service recovery episode. This process has distributive, interactional, and procedural elements; in other words, it is an assessment of whether the failure and resulting consumer loss were fairly reversed in their substantive content, whether the recovery experience was interpersonally pleasant and whether adequate organizational procedures guided the process, respectively.
After a decade of testing, there is plenty of empirical evidence (Gelbrich \& Roschk, 2011; Orsingher et al., 2010) that consumer justice perceptions predict both satisfaction with service recovery and overall satisfaction. Furthermore, we now know that not all prongs of the justice model are created equal: distributive justice in general is a better predictor of satisfaction with recovery (Orsingher et al., 2010) than interactive and procedural justice; however, the reverse appears to be true for overall service satisfaction (Gelbrich \& Roschk, 2011).

It is important to note that justice theory is a cognitive model. Even though affective and conative/behavioral processes are intertwined with cognitive ones, they are distinct (Shoefer, 2008). We suggest that research involving firm responses in service recovery should explore affective and behavioral phenomena, beyond cognitive concepts.

The objective is to study the impact of phenomena not studied before in the context of affective and conative recovery tactics and to expand the theoretical arsenal, incorporating the theories of "emotional labor" and "employee affective delivery".

The contribution of this paper is the assessment of the impact of two such non-cognitive service recovery tactics that firms actually use: the impact of displaying emotional involvement by the provider of the service recovery, conceptualized as employee affective delivery (Tsai \& Huang, 2002), and intentionally allowing some perceived control (Bateson, 2000) to consumers participating in recovery. By doing this, we expand the cognitively-dominated understanding of service recovery through the inclusion of the impact of affective and conative/behavioral service recovery tactics.

\section{LITERATURE REVIEW}

In this section, we discuss the relevant concepts incorporated in our study. First, the concept of employee affective delivery will be introduced, 
followed by customer perceived control, and compensation as the most often cited service recovery tool.

\subsection{Employee affective delivery}

The study of emotions in marketing and services is often conceptualized as an important antecedent to consumer satisfaction (Bagozzi, Gopinath \& Nyer, 1999; Mattila \& Enz, 2002; Namkung \& Jang, 2010; Oliver, 1993; Szymanski \& Henard, 2001; Westbrook \& Oliver, 1991). Service failures often elicit strong negative affect (Bonifield \& Cole, 2007; Gelbrich, 2010; McCoII-Kennedy, Patterson, Smith \& Brady, 2009). In service recovery, consumer emotions were also shown to play a significant role as antecedents to satisfaction (Chebat \& Slusarczyk, 2005; Del Río-Lanza, Vázquez-Casielles \& Díaz-Martín, 2009; Dewitt \& Brady, 2003; Lin \& Mattila, 2010; McColl-Kennedy \& Sparks, 2003; Schoefer, 2008; Schoefer \& Diamantopoulos, 2008; Schoefer \& Ennew, 2005; Smith \& Bolton, 2002).

When modeling the role of emotions in service recovery, the literature postulates consumer emotional reaction as a mediating variable between cognitive justice evaluations and satisfaction with recovery (Chebat \& Slusarczyk, 2005; Del Río-Lanza et al., 2009; McColl-Kennedy \& Sparks, 2003; Schoefer, 2008; Schoefer \& Diamantopoulos, 2008; Schoefer \& Ennew, 2005). Implicitly or explicitly, this approach uses the appraisal theory from social psychology, suggesting that the origin of emotions lies in cognitive evaluations (Smith \& Lazarus, 1993; Scherer, 1999; cited by Manstead, 2010).

What the direct service recovery literature addresses less is the impact of employee, rather than consumer emotions. The impact of employees' emotional expressions is in the focus of only a few studies. Delcourt, Gremler van Riel, and van Birgelen (2013) studied the effects of perceived employee emotional competence on customer satisfaction. Grandey, Fisk, Mattila, Jansen and Sideman (2005) examined the impression management strategies used by service providers, more specifically, the authentici- ty of positive emotional displays which proved to increase the overall satisfaction with the service encounter. Mattila, Grandey and Fisk (2003) also confirmed the impact of emotional display with an emphasis on the interplay of gender and affective tone. The concept of employee affective delivery is used to describe those phenomena which can be defined as "the act of expressing socially desired emotions during service transactions" (Ashforth \& Humphrey, 1993, p. 88-89).

Furthermore, while the recovery literature uses appraisal theory as the dominant explanation for consumer emotions in recovery, this may not be the only or the best-fitting model for explaining the impact of employee emotions. We suggest that bringing in theories from foundational literature on organizational behavior and different schools of emotional theory in social psychology can help fill this gap.

The so-called "emotional contagion", for example, suggests that humans tend to mimic each other's affective states, often at lower levels of consciousness (Hatfield, Cacioppo \& Rapson, 1994; Neumann \& Strack, 2000). The social-functional theories of emotions provide another explanation why employee's affective delivery may influence consumer reactions to service recovery. Emotions observed can provide social utility for the observer (Keltner \& Haidt, 1999; Parkinson, 1996; Van Kleef, 2009).

The field of organizational behavior has always paid a lot of attention to emotions, but research on affect in organizations is currently experiencing a strong revival. The reason for the heightened interest is clear: positive affect among employees is known to be positively correlated to almost all important human resource management variables, such as performance, decision making, creativity, turnover/absence, prosocial behavior, negotiation, conflict resolution, team behavior, and leadership (Barsade \& Gibson, 2007). It is important to note that, while employee emotion has been shown to be a critical predictor of service recovery success, its effectiveness is likely to be subject to cultural variation. 


\subsection{Customer perceived control}

The other important recovery tactic incorporated in our design is "perceived control". Perceived control is defined as consumers' ability to exert some level of influence on the manner in which the service recovery process is administered (Hui \& Bateson, 1991). While complaining can already be considered proactive behavior, post-complaint, there are also opportunities for firms to allow consumers to be active and participative. We expect this possibility for active behavioral engagement to result in heightened satisfaction with the recovery.

The most directly relevant support comes from the theory of perceived control; the idea that in service encounters participants (both employees and consumers) are motivated to gain mastery of the situation, and if they feel they do, they are more satisfied with the encounter than if they do not (Bateson, 2000).

The roots of control theory in psychology date back some time. It has been long recognized that the need for control over one's environment is a basic human motive and predictor of attitudinal and behavioral change (Ajzen, 1991; Averill, 1973; Rodin, 1990). Research on perceived control is rather limited in the marketing literature; the few studies linked to service recovery (Mattila \& Cranage, 2005; Karande, Magnini \& Tam, 2007) confirm that giving people control over an element of the service encounter or following service failure increases the overall post-failure satisfaction.

\subsection{Compensation}

In their complaint handling efforts, firms often offer compensation to customers in various forms of financial or non-financial remuneration. Prior research on compensation demonstrates that compensation may offset the loss experienced by the customer and that it leads to a higher degree of satisfaction with the service encounter and repurchase intentions (Chebat \& Slusarczyk, 2005; Smith et al., 1999). It is also assumed that compensation increases satisfaction following the complaint, and this effect is noticeable compared to other organizational responses, such as apology or promptness (Davidow, 2003; Orsingher et al., 2010). An important implication of this stream of research is that compensation (as any other service recovery attribute) cannot be studied in isolation. For instance, it is known that the poor treatment of customers decreases the positive impacts of compensation (Tax et al., 1998). While compensation is not the central focus of our study, the interaction and the potential trade-offs between compensation and other service recovery tools are expected to have relevant theoretical and managerial implications.

\section{RESEARCH HYPOTHESES}

From a multitude of theoretical approaches, the employee affective delivery theory is the most relevant for our purposes. Tsai and Huang (2002) find empirical support for employee affective delivery having a positive effect on consumer moods, time spent at retail locations, and ultimately, purchase intentions.

Conceptualizing the display of emotions as employee affective delivery we posit:

H1: Levels of consumer satisfaction with service recovery are higher if the level of employee affective delivery is higher (high vs. low employee affective delivery) during recovery.

There is empirical support for the theory of perceived control in services, as well. Hui and Bateson (1991) show that perceived control is related to service pleasantness, as perceived by consumers. Research results also suggest that higher degrees of perceived control lead to higher satisfaction (O'Driscoll \& Beehr, 2000) and decreased perceived risk (Nordgren, Van der Pligt \& Van Harreveld, 2007).

However, there is only limited research available on consumers' perceived control in a service recovery context. The most relevant study to our knowledge is that of Chang (2008), who found that consumers' perceived control over the res-

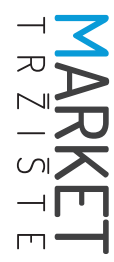


olution of service failure is positively correlated to their satisfaction with recovery in an on-line context.

On the theoretical basis of the perceived control literature, we therefore formulate the following hypothesis:

H2: Levels of consumer satisfaction with service recovery are higher if consumers have control over the recovery process.

\subsection{Employee affective delivery - compensation interaction}

We do not propose a separate hypothesis for the main effect for compensation because there is overwhelming empirical evidence for this relationship already (Orsingher et al., 2010). We will measure this relationship, however, mainly for the purpose of testing interactions. Testing the interactions among service recovery attributes is a high research priority (Davidow, 2003) and we will heed this advice.

We have reasons to expect that an interaction between employee affective delivery and compensation exists. When no emotions are displayed, emotional contagion and other emotional processes may not be operative and, as a result, rational-cognitive evaluative processes may come to the foreground (Hatfield et al., 1994; Neumann \& Strack, 2000; Pugh, 2001). Furthermore, as functional theories of emotions would predict, without emotions displayed, their functional utility (Keltner \& Haidt, 1999; Parkinson, 1996; Tooby \& Cosmides, 2008; Van Kleef, 2009; Van Kleef, Anastasopoulou \& Nijstad, 2010a; Van Kleef, De Dreu, Manstead \& Mark, $2010 \mathrm{~b}$ ) is lost; thus, consumers need to use other cues (i.e. cognitive ones) to orient their appraisal of the recovery situation. Under such stricter cognitive evaluation conditions, functional/rational stimuli (i.e. whether the "hard currency" of compensation is offered) matter more than when emotions "temper" hard rational evaluations. Social cognitive theories of emotions such as the Affect Infusion Model (Forgas, 1995; Forgas, 1998; Kim \& Kanfer, 2009) suggest a similar prediction, in that positive affect is known to color judgment and to some extent impede cognitive information processing.

Therefore, our third hypothesis is:

H3: There is an interaction effect between employee affective delivery and compensation on consumer satisfaction: compensation affects more the consumers who are not exposed to employee affect than those who are.

\subsection{Employee affective delivery - customer perceived control interaction}

As shown above, behavioral control is a strong human motivator. The perception that one is in control is a key predictor of general emotional stability and situational positive affect (Averill, 1973; Bye \& Pushkar, 2009). This positive emotional effect of being in control has been proposed to exist in services marketing as well (Bateson, 2000). Applying this relationship to our context, if customers are given control over recovery, they are expected to experience positive emotions. These positive emotions, on the other hand, may hinder primitive emotional contagion from taking full effect because emotional intensity (just as arousal and other basic psychological processes) is subject to ceiling effects; one cannot be infinitely happy (affectively elevated), rather, there is a maximum threshold to the amplitude of dynamic affect states (Verduyn, Van Mechelen, Tuerlinckx, Meers \& Van Coillie, 2009). In other words, positive emotions arising from perceived control may cancel out emotions arising from primitive emotional contagion via employee affective delivery. When consumers are given control, employee affective contagion may have lower motivational force than when it is introduced on its own.

Another argument relates to the concept of counterfactual thinking (Roese, 1997; McCoII-Kennedy \& Sparks, 2003). To put it simply, counterfactual thinking means that after service failure consumers engage in different evaluating processes: what could have occurred, what should have occurred, and how it would have been if the service provider had taken a differ- 
ent action. It is likely that giving customers a choice over service recovery blocks counterfactual thinking. If there is no sign of affect from the employee, counterfactual thinking may kick in. However, by giving perceived control to consumers, the negative effect resulting from the lack of affective display may be altered.

We therefore hypothesize:

H4: There is an interaction effect between employee affective delivery and customer perceived control on consumer satisfaction: employee emotions affect the consumers who are not given control in the service recovery process more than those who are.

\subsection{Customer perceived control - compensation interaction}

Similarly to $\mathrm{H} 4$, the employee action of providing compensation vs. not providing compensation may have a higher/lower positive impact on satisfaction, depending on whether customers are given control. As posited under $\mathrm{H} 4$, being in control is a strong motivator that may cancel out other motivators, in this case, the rational incentive of monetary compensation. While not being tested in the service recovery literature to our knowledge, basic psychological theories of motivation conflict have long demonstrated the existence of such crowding out effects involving diverse motivational forces (Lewin, 1935; Miller, 1959).

Therefore, our last hypothesis focuses on an interaction effect between perceived control and compensation:

H5: There is an interaction effect between customer perceived control and compensation on consumer satisfaction: compensation affects the consumers who are not given control in the service recovery process more than those who are.

\section{RESEARCH METHODS}

We chose a context - restaurants - which is widely used in service failure/recovery research (Baker, Meyer \& Johnson, 2008; Bitner, Booms \&
Tetreault, 1990; Mattila \& Patterson, 2004; Warden, Huang \& Wu, 2008; Silber, Israeli, Bustin \& Ben Zvi, 2009). As restaurants are highly susceptible to failure incidents, it is easy for customers to switch after a bad experience. Furthermore, eating in a restaurant is a service with which most people have at least some experience.

\subsection{Manipulation development}

We developed manipulation scenarios, reflecting the core constructs of employee affective delivery and customer perceived control. We also included compensation scenarios, with the rationale of testing for interactions, as suggested above.

When developing the scenarios, we relied on previous literature. For the perceived control condition, we adopted the manipulation used by Hui and Bateson (1991). The compensation manipulation was based on Smith and others (1999). As shown above, we conceptualized employee affective delivery differently from interactional justice. Also, employee affective delivery has not been used as an independent variable in service recovery research; as a result, when developing the employee affect condition, we relied on general psychological and organizational behavior research. As a direct experimental manipulation source we used Grayson (1998) while consulting measures from non-experimental designs in the area as complements (Hatfield et al., 1994; Pugh, 2001; Tsai \& Huang, 2002)

Four expert judges, who are faculty members in services marketing, reviewed and commented on the scenarios and the questionnaire. Slight modifications in wording were implemented to improve ecological validity. Next, according to the recommendations of Perdue and Summers (1986), manipulations were checked in a quantitative pilot study, which was independent of the main experiment. The manipulation check indicated that the manipulations were effective, with a significant difference between test and control groups for all conditions. The manipulation check for the three independent

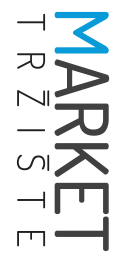




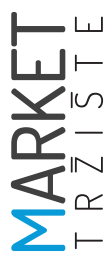

variable was as follows: for compensation one item was used based on Mattila and Cranage (2005): "The restaurant gave me compensation for the poor service", where $M$ (comp) $=4.42$ vs. $M($ no comp $)=1.56, F(1,339)=678.414, p<0.05$. For employee affective delivery two-item measure was used based on Hocutt, Bowers and Donovan (2006) (sample item: "The server seemed to care about my feelings"; $\alpha=.91$ ), $M$ (affect) $=4.23$ vs. $M$ (no affect $)=1.37, F(1,338)=2009.367, p<0.05$. For customer perceived control a four-item scale was used for manipulation check based on Hui and Bateson (1991) (sample item: "I had choice in deciding whether to wait or leave."; $\alpha=.95)$, M (control) $=4.5$ vs. $M($ no control) $=2.7, F(1,339)=200.291$, $p<0.05)$. We also checked the scenarios for realism by asking respondents about "How realistic is this situation?" and "Can this situation happen in everyday life?", where the means scores on a 5-point Likert-scale were between 4.14 and 4.22 for the eight scenarios, suggesting scenarios were perceived highly realistic by respondents.

\subsection{Main study}

A 2x2×2 between-subject experimental design was used with employee affective delivery, customer perceived, and compensation as independent variables. Respondents were randomly assigned to the experimental conditions.

The final manipulation scenarios asked respondents to imagine visiting a restaurant and ordering drinks and a meal. Service failure constituted a significant delay in service, while recovery had different characteristics along the dependent manipulations. The manipulations were incorporated into the scenarios on either a yes or no level, according to the following:

- Low employee affective delivery: "The waiter tells you, looking rather indifferent, that your order will be late [...] You can tell that that the waiter is unaffected by the incident - it seems he does not really care about it."

- Employee affective delivery: "The waiter tells you, looking really worried, that your order will be late [...] You can tell that the waiter is concerned about the incident - it seems he is feeling bad."

- No customer perceived control: "Because the waiter told you the bad news after thirty minutes, you feel you have little control over the situation."

- Customer perceived control: "Because the waiter told you the bad news right after you ordered, you feel you have the choice to decide what to do next - you feel in control."

o No compensation: "[...] without offering any compensation."

o Compensation: "You are offered a $10 \%$-off coupon for your next visit to the restaurant."

Satisfaction with service recovery was measured on a three-item scale ("In my opinion, in this particular case the restaurant provided a satisfactory resolution to the problem."; "The waiter's response to my problem was much worse than expected/much better than expected."; "Regarding this particular event, I would be satisfied with the restaurant."), adopted from previous research (Maxham \& Netemeyer, 2002; Smith et al., 1999).

Participants were recruited from a commercial panel provider. The total sample size was $N=580$ (Gender: male $=49 \%$, female $=51 \%$; Age: Up to $29=37 \%, 30-49=33 \%$, Over 50=30 \%). The 8 different scenarios, resulting from the $2 \times 2 \times 2$ design, were randomly assigned to participants in the sample.

\section{RESULTS}

The effect of the independent variables (compensation, employee affective delivery, perceived control) on the dependent variable (customer satisfaction with recovery scale, three items simple arithmetic mean, Cronbach's $\alpha=0.86$ ) was tested by the factorial analysis of the variance test. Results indicate that all three main effects are statistically significant - for compensation: $F(1,572)=52.08, p<.05$; for employee affective delivery: $F(1,572)=463.51$, $p<.005$; for customer perceived control: $F(1$, 
$572)=26.26, p<.05$. The cell means are reported in Table 1, rows 1-6. These results provide support for $\mathrm{H} 1$ and $\mathrm{H} 2$.
A two-way interaction between employee affective delivery and compensation was found to be significant: $F(1,572)=11.554, p<.05)$. The cell

TABLE 1: Descriptive Statistics

\begin{tabular}{|l|c|c|}
\hline Experimental condition & Mean & SD \\
\hline Compensation & 3.25 & 0.98 \\
\hline No compensation & 2.74 & 1.19 \\
\hline Affective delivery & 3.70 & 0.75 \\
\hline No affective delivery & 2.26 & 0.97 \\
\hline Perceived control & 3.23 & 1.02 \\
\hline No perceived control & 2.81 & 1.17 \\
\hline Compensation with affective delivery & 3.82 & 0.72 \\
\hline Compensation without affective delivery & 2.64 & 0.86 \\
\hline No compensation with affective delivery & 3.57 & 0.76 \\
\hline No compensation without affective delivery & 1.85 & 0.91 \\
\hline Compensation with perceived control & 3.31 & 1.02 \\
\hline Compensation without perceived control & 3.19 & 0.95 \\
\hline No compensation with perceived control & 3.12 & 1.02 \\
\hline No compensation without perceived control & 2.44 & 1.25 \\
\hline Affective delivery with perceived control & 3.74 & 0.81 \\
\hline Affective delivery without perceived control & 3.65 & 0.68 \\
\hline No affective delivery with perceived control & 2.60 & 0.90 \\
\hline No affective delivery without perceived control & 1.98 & 0.93 \\
\hline
\end{tabular}

These main effects, however, are qualified by significant two-way interactions. The cell means are reported in Table 1, and the analysis of variance test results in Table 2 . The interaction effects are shown in Figures 1-3. means indicate that the difference in satisfaction ratings between the conditions of "compensation offered" and "compensation not offered" is larger without affective delivery than with it ( $M$ (comp-affect) $=3.82$ vs. $M$ (no comp-affect) $=3.57$

TABLE 2: Analysis of variance results

\begin{tabular}{|c|c|c|c|c|c|}
\hline Source & SS & df & MS & $\mathbf{F}$ & $\mathbf{p}$ \\
\hline Between treatments & 381.874 & 7 & 54.553 & & \\
\hline Compensation & 31.245 & 1 & 31.245 & 52.079 & $<.05$ \\
\hline Employee affective delivery & 278.090 & 1 & 278.090 & 463.516 & $<.05$ \\
\hline Perceived control & 15.753 & 1 & 15.753 & 26.256 & $<.05$ \\
\hline $\begin{array}{l}\text { Compensation x Employee affective } \\
\text { delivery }\end{array}$ & 6.932 & 1 & 6.932 & 11.554 & $<.05$ \\
\hline Compensation $x$ Perceived control & 6.694 & 1 & 6.694 & 11.158 & $<.05$ \\
\hline $\begin{array}{l}\text { Employee affective delivery x Perceived } \\
\text { control }\end{array}$ & 8.682 & 1 & 8.682 & 14.471 & $<.05$ \\
\hline Within treatments & 343.175 & 572 & .600 & & \\
\hline Total & 5981.111 & 580 & & & \\
\hline
\end{tabular}


with affective delivery; $M$ (comp-no affect) $=2.64$ vs. $M$ (no comp-no affect) $=1.87$ without affective delivery; see Figure 1). Furthermore, delivering positive affect - when no compensation is offered - results in higher satisfaction ratings than when offering compensation without affect $(M$ (no comp-affect) $=3.57$ vs. $M$ (comp-no affect $=2.64$ ). This finding provided support for the interaction hypothesis between employee affective delivery and compensation $(\mathrm{H} 3)$.

FIGURE 1: Interaction effects between employee affective delivery and compensation

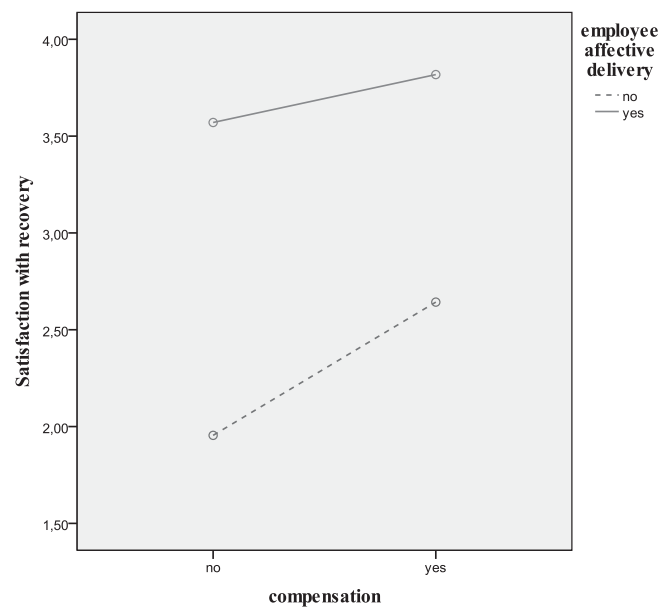

A two-way interaction between perceived control and employee affective delivery was also significant: $F(1,572)=14.471, p<.05)$. The results indicate that the difference in satisfaction ratings between the conditions of "employee affective delivery" and "no employee affective delivery" is larger without perceived control than with it: $(M$ (affect-control) $=3.74$ vs. $M$ (no affect-control) $=2.60$ with perceived control; $M$ (affect-no control)=3.65 vs. $M($ no affect-no control)=1.98 without perceived control; see Figure 2).

This finding was consistent with $\mathrm{H} 4$.

A final two-way interaction between perceived control and compensation was also found to be significant: $F(1,572)=11.158, p<.05$; see Figure 3. The results confirm the impact of compensation: the difference in satisfaction ratings
FIGURE 2: Interaction effects between employee affective delivery and customer perceived control

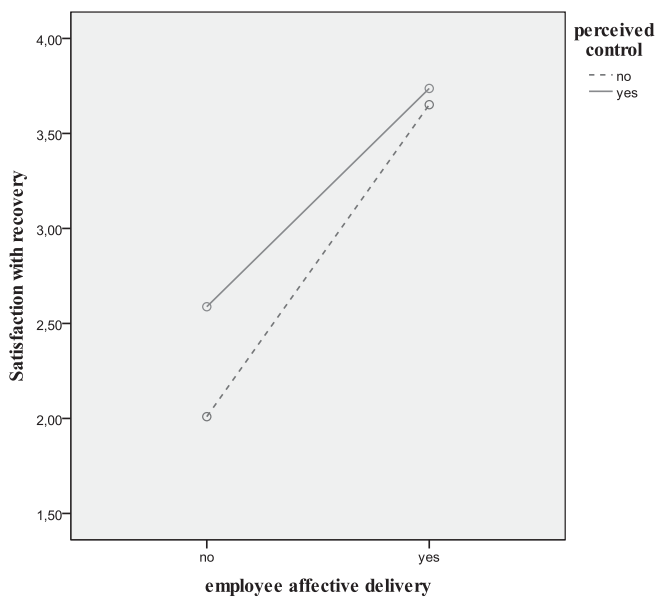

FIGURE 3: Interaction effects between perceived control and compensation

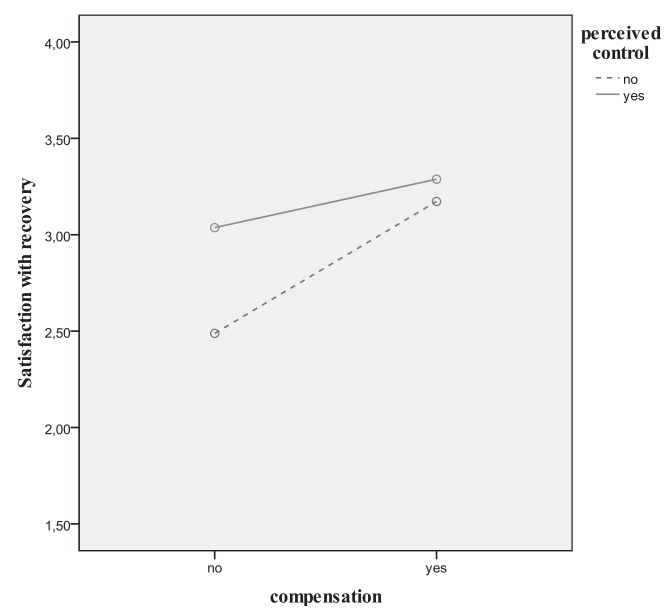

between the conditions of "compensation offered" and "compensation not offered" is larger without perceived control than with it: (M (comp-control)=3.31 vs. $M$ (no comp-control)=3.12 with perceived control; $M$ (comp-no control)=3.19 vs. $M$ (no comp-no control) $=2,44$ without perceived control; see Figure 3). In other words, a significant interaction effect exists between compensation and perceived control, supporting $\mathrm{H} 5$. 
One has to note that, in the case of all three interactions documented above, in the absence of one factor the effect of the other factor on the outcome variable increased. This means, for instance, if the manipulation of perceived control is absent, as a result of offering compensation, satisfaction increases more than under the scenario when the manipulation of perceived control is also present. The same is true for the employee affective delivery-compensation and the employee affective delivery-perceived control interaction pairs, as the figures illustrate.

\section{DISCUSSION}

Research reported in this paper extends the literature on service recovery by testing the consumer impact of organizational actions such as employee affective delivery and allowing consumer recovery control, which are conceptualized differently from the way traditional justice theory research conceptualizes organizational actions (distributive, interactional, procedural justice). Our study found evidence that emotions displayed by service workers providing recovery as well as the allowance of behavioral control for consumers have a positive impact on customer satisfaction with recovery. These results suggest both theoretical and practical implications.

\subsection{Research implications}

We contributed to the literature by showing the impact of characteristically "non-cognitive" phenomena in service recovery: emotions and behavioral control. Our research demonstrates the importance of emotional phenomena in the context of service recovery, corroborating research in other contexts, such as organizational behavior (Barsade \& Gibson 2007), general marketing (Bagozzi et al., 1999), and general services marketing research (Du, Fan \& Feng, 2011). Theories such as that of emotional labor and employee affective delivery have proven useful in making predictions about the consumer impact of service recovery. Similarly, our study has shown the relevance of a conative/behavi- oral concept: behavioral control (Hui \& Bateson, 1991) in the service recovery context.

Our research proves that organizational actions are never perceived in isolation by consumers; there are rich interactions between different forms of recovery attempts. Results have demonstrated the existence of interactions among each combination of compensation, employee affect, and perceived control. The importance of interactions in the study of service recovery effects has been well-recognized (Davidow, 2003), and our research provides further corroboration. Our interaction results also provide an interesting addition to our understanding of the relative strength of drivers of service recovery satisfaction.

\subsection{Managerial implications}

First, these findings suggest the existence of a potential trade-off between compensation and other non-cognitive, non-distributive-type recovery tactics, such as employee affective delivery or perceived control. As we have shown, emotions of the waiter and the allowance of consumer behavioral control have as significant an impact on satisfaction as compensation does. Moreover, because of the significant interactions, the effectiveness of compensation as a recovery tactic is qualified by employee affective delivery and consumer perceived control.

The implication for managers is that compensation may not be the most efficient way of increasing satisfaction with service recovery. For instance, when compensation is too costly or difficult, displaying emotions or behavioral control to consumers may be a viable economic alterative to hard cash. Since delivering positive employee affect to consumers or giving them perceived control over the recovery may result in similar satisfaction levels to when compensation is dispensed, such soft recovery techniques may be more profitable from a managerial economics perspective.

Second, even in situations when managers would not wish to abandon hard currency compensation, attention paid to emotionally intelli-

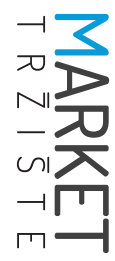




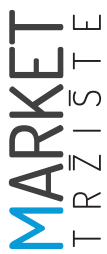

gent recovery can yield high dividends in customer satisfaction. Hiring emotionally intelligent service workers, who are capable of positive affective delivery, will result in more satisfied consumers and strengthen the impact of other service recovery tactics. Since emotional contagion theory suggests that emotional infection works both ways (i.e. from the waiter to the consumer and from the consumer to the waiter), it is important to recruit service workers who are emotionally intelligent enough to resist negative consumer emotion and at the same time display positive affect. We corroborate previous research in general management, suggesting the importance of employee emotional intelligence in exchanges (Kidwell, Hardesty, Murtha \&Sheng, 2011).

Third, behavioral control can be a very successful and cost-effective service recovery tactic, supporting previous recommendations for allowing consumer control (Hui \& Bateson, 1991) and consumer participation and co-creation (Prahalad \& Ramaswamy, 2000). Just as in general marketing and services marketing contexts, allowing some control in how service recovery would take place (such as giving consumers options to decide how to resolve a service failure) can result in satisfaction levels comparable to more expensive (e.g. compensation) tactics.

\subsection{Limitations and future research}

As any research, this study also has some limitations. First, while we made every effort to make sure the scenario manipulations are valid and reliable through a multi-step strategy of manipulation development and testing, some respondents may perceive scenarios as less realistic than real-life, in-person interactions. Other methods, such as the use of actors or audiovisual tools can complement our methodology; while we faced budgetary and practical constraints, other researchers can triangulate the results by using these innovative methods. Second, individual differences may exist in susceptibility to emotional contagion (Doherty, 1997;
Du et al., 2011). For the sake of parsimony and on account of our interest in general consumer processes, we did not focus on individual differences - an area that can be investigated in the future. Profiling consumers for susceptibility to emotional contagion effects can add to our arsenal of efficient service recovery techniques.

There are many avenues for future research. First, as we argued, the re-conceptualization of firm actions in the service recovery process as heterogeneous and non-conforming to the "mirror-image" assumption of justice theory research can yield significant benefits. Indeed, even if firms providing recovery take into consideration how consumer reactions to recovery can be grouped (distributive, interactional, procedural), they often "just do what they do," not conforming to any scheme. The grounded theory approach to uncovering such non-normative service recovery techniques (of what firms actually do) and their consumer impact can greatly enrich the field. Second, the mediating processes of employee affective delivery can be traced using structural equation modeling techniques. Employee perceptions of the type impact (distributive, interactional, procedural, or other) can be contrasted with real consumer processes. Third, moderating factors can be investigated. For instance, failure severity, the length of relationship with the service provider, or the level of perceived risk in the exchange may moderate the effect of employee affective delivery. Fourth, while we followed the social psychological tradition of theorizing general processes rather than the effects of individual difference and cultural variables, these are also important research avenues to pursue in the future.

In conclusion, there is much to be learned in the context of service recovery about the effects of employee emotions and customer control, emotional/behavioral factors that have so far remained outside of the cognitive realm of justice theory. Our study contributes to the theoretical opening up of the well-established territory of justice theory in a service recovery context. 


\section{References}

1. Ajzen, I. (1991). The theory of planned behavior. Organizational Behavior \& Human Decision Processes, 50(2), 179-211.

2. Ashforth, B. E., \& Humphrey, R. H. (1993). Emotional labor in service roles: The influence of identity. Academy of Management Review, 18(1), 88-115.

3. Averill, J.R. (1973). Personal control over aversive stimuli and its relationship to stress. Psychological Bulletin, 80(4), 286-303.

4. Bagozzi, R. P., Gopinath, M., \& Nyer, P. U. (1999). The role of emotions in marketing. Journal of the Academy of Marketing Science, 27(2), 184-206.

5. Baker, T. L., Meyer, T., \& Johnson, J. D. (2008). Individual differences in perceptions of service failure and recovery: The role of race and discriminatory bias. Journal of the Academy of Marketing Science, 36(4), 552-564.

6. Barsade, S. G., \& Gibson, D. E. (2007). Why does affect matter in organizations?. Academy of Management Perspectives, 21(1), 36-59.

7. Bateson, J. E. G. (2000). Perceived control and the service experience. In: T. A. Swartz \& D. lacobucci (Eds.). Handbook of Services Marketing and Management, (pp. 127-144). Thousand Oaks, CA: Sage.

8. Bitner, M. J., Booms, B. H., \& Tetreault, M. S. (1990). The service encounter: Diagnosing favorable and unfavorable incidents. Journal of Marketing, 54(1), 71-84.

9. Bonifield, C., \& Cole, C. (2007). Affective responses to service failure: Anger, regret, and retaliatory versus conciliatory responses. Marketing Letters, 18(1/2), 85-99.

10. Bye, D. \& Pushkar, D. (2009). How need for cognition and perceived control are differentially linked to emotional outcomes in the transition to retirement. Motivation \& Emotion, 33(3), 320332.

11. Chang, C. C. (2008). Choice, perceived control, and customer satisfaction: The psychology of online service recovery. CyberPsychology \& Behavior, 11(3), 321-328.

12. Chebat, J-C., \& Slusarczyk, W. (2005). How emotions mediate the effects of perceived justice on loyalty in service recovery situations: An empirical study. Journal of Business Research, 58(5), 664-673.

13. Davidow, M. (2003). Organizational responses to customer complaints: What works and what doesn't. Journal of Service Research, 5(3), 225-250.

14. Del Río-Lanza, A. B., Vázquez-Casielles, R., \& Díaz-Martín, A. M. (2009). Satisfaction with service recovery: Perceived justice and emotional responses. Journal of Business Research, 62(8), 775-781.

15. Delcourt, C., Gremler, D. D., van Riel, A. C. R., \& van Birgelen, M. (2013). Effects of perceived employee emotional competence on customer satisfaction and loyalty. Journal of Service Management, 24(1), 5-24.

16. Dewitt, T., \& Brady, M. K. (2003). Rethinking service recovery strategies: The effect of rapport on consumer responses to service failure. Journal of Service Research, 6(2), 193-207.

17. Doherty, R. W. (1997). The emotional contagion scale: A measure of individual differences. Journal of Nonverbal Behavior, 21(2), 131-154.

18. Du, J., Fan, X., \& Feng, T. (2011). Multiple emotional contagions in service encounters. Journal of the Academy of Marketing Science, 39(3), 449-466.

19. Forgas, J. P. (1995). Mood and judgment: The affect infusion model (AIM). Psychological Bulletin, $117(1), 39-66$.

20. Forgas, J. P. (1998). On being happy and mistaken: Mood effects on the fundamental attribution error. Journal of Personality \& Social Psychology, 75(2), 318-331.

21. Gelbrich, K. (2010). Anger, frustration, and helplessness after service failure: Coping strategies and effective informational support. Journal of the Academy of Marketing Science, 38(5), 567-585. 
22. Gelbrich, K., \& Roschk, H. (2011). A meta-analysis of organizational complaint handling and customer responses. Journal of Service Research, 14(1), 24-43.

23. Grandey, A. A., Fisk, G. M., Mattila, A. S., Jansen, K. J., \& Sideman, L. A. (2005). Is 'service with a smile' enough? Authenticity of positive displays during service encounters. Organizational Behavior \& Human Decision Processes, 96(1), 38-55.

24. Grayson, K. (1998). Customer responses to emotional labour in discrete and relational service exchange. International Journal of Service Industry Management, 9(2), 126-154.

25. Hart, C. W., Heskett, J. L., \& Sasser, W. E. Jr. (1990). The profitable art of service recovery. Harvard Business Review, 68(July-August), 148-156.

26. Hatfield, E., Cacioppo, J. T., \& Rapson, R. L. (1994). Emotional Contagion. Cambridge: Cambridge University Press.

27. Hocutt, M. A., Bowers, M. R., \& Donavan, D. T. (2006). The Art of Service Recovery: Fact or Fiction? Journal of Services Marketing, 20(3), 199-207.

28. Homans, G. C. (1961). Social Behavior: Its Elementary Forms. New York, NY: Harcourt, Brace \& World.

29. Hui, M. K., \& Bateson, J. E. G. (1991). Perceived control and the effects of crowding and consumer choice on the service experience. Journal of Consumer Research, 18(2), 174-184.

30. Karande, K., Magnini, V. P., \& Tam, L. (2007). Recovery voice and satisfaction after service failure: An experimental investigation of mediating and moderating factors. Journal of Service Research, 10(2), 187-203.

31. Keltner, D., \& Haidt, J. (1999). Social functions of emotions at four levels of analysis. Cognition \& Emotion, 13(5), 505-521.

32. Kidwell, B., Hardesty, D. M., Murtha, B. R., \& Sheng, S. (2011). Emotional intelligence in marketing exchanges. Journal of Marketing, 75(1), 78-95.

33. Kim, M. Y., \& Kanfer, R. (2009). The joint influence of mood and a cognitively demanding task on risk-taking. Motivation \& Emotion, 33(4), 362-372.

34. Lewin, K. (1935). A Dynamic Theory of Personality: Selected Papers. New York, NY: McGraw-Hill.

35. Lin, I. Y., \& Mattila, A. S. (2010). Restaurant Servicescape, Service Encounter, and Perceived Congruency on Customers' Emotions and Satisfaction. Journal of Hospitality Marketing \& Management, 19(8), 819-841.

36. Manstead, A. S. R. (2010). Social psychology of emotion. In: R. F. Baumeister \& E. J. Finkel (Eds.). Advanced Social Psychology: The State of the Science, (pp. 101-137). Oxford: Oxford University Press.

37. Mattila, A. S., \& Cranage, D. (2005). The impact of choice on fairness in the context of service recovery. Journal of Services Marketing, 19(5), 271-279.

38. Mattila, A. S., \& Enz, C. A. (2002). The role of emotions in service encounters. Journal of Service Research, 4(4), 268-277.

39. Mattila, A. S., \& Patterson, P. G. (2004). Service recovery and fairness perceptions in collectivist and individualist contexts. Journal of Service Research, 6(4), 336-346.

40. Mattila, A. S., Grandey, A. A., \& Fisk, G. M. (2003). The interplay of gender and affective tone in service encounter satisfaction. Journal of Service Research, 6(2), 136-143.

41. Maxham, J. G. I., \& Netemeyer, R. G. (2002). Modeling customer perceptions of complaint handling over time: The effects of perceived justice on satisfaction and intent. Journal of Retailing, 78(4), 239-252.

42. McColl-Kennedy, J. R., \& Sparks, B. A. (2003). Application of fairness theory to service failures and service recovery. Journal of Service Research, 5(3), 251-266.

43. McColl-Kennedy, J. R., Patterson, P. G., Smith, A. K., \& Brady, M. K. (2009). Customer rage episodes: Emotions, expressions and behaviors. Journal of Retailing, 85(2), 222-237. 
44. McCollough, M. A., Berry, L. L., \& Yadav, M. S. (2000). An empirical investigation of customer satisfaction after service failure and recovery. Journal of Service Research, 3(2), 121-137.

45. Miller, N. E. (1959). Liberalization of basic S-R concepts: Extensions to conflict behavior, motivation and social learning. In: S. Koch (Ed.). Psychology: A Study of a Science. Vol. 2, (pp. 196-292), New York, NY: McGraw-Hill.

46. Namkung, Y., \& Jang, S. C. (2010). Effects of perceived service fairness on emotions, and behavioral intentions in restaurants. European Journal of Marketing, 44(9/10), 1233-1259.

47. Neumann, R., \& Strack, F. (2000). 'Mood contagion': The automatic transfer of mood between persons. Journal of Personality \& Social Psychology, 79(2), 211-223.

48. Nordgren, L. F., Van Der Pligt, J., \& Van Harreveld, F. (2007). Unpacking perceived control in risk perception: The mediating role of anticipated regret. Journal of Behavioral Decision Making, 20(5), 533-544.

49. O'Driscoll, M. P., \& Beehr, T. A. (2000). Moderating effects of perceived control and need for clarity on the relationship between role stressors and employee affective reactions. Journal of Social Psychology, 140(2), 151-159.

50. Oliver, R. L. (1993). Cognitive, affective, and attribute bases of the satisfaction response. Journal of Consumer Research, 20(3), 418-430.

51. Orsingher, C., Valentini, S., \& De Angelis, M. (2010). A meta-analysis of satisfaction with complaint handling in services. Journal of the Academy of Marketing Science, 38(2), 169-186.

52. Parkinson, B. (1996). Emotions are social. British Journal of Psychology, 87(4), 663-683.

53. Perdue, B. C., \& Summers, J. O. (1986). Checking the success of manipulations in marketing experiments. Journal of Marketing Research, 23(4), 317-326.

54. Prahalad, C. K., \& Ramaswamy, V. (2000). Co-opting customer competence. Harvard Business Review, 78(1), 79-87.

55. Pugh, S. D. (2001). Service with a smile: Emotional contagion in the service encounter. Academy of Management Journal, 44(5), 1018-1027.

56. Rodin, J. (1990). Control by any other name: Definitions, concepts and processes. In: J. Rodin, C. Schooler \& K. W. Schaie (Eds.). Self-directedness: Cause and Effects throughout the Life Course, (pp. 1-15). Hillsdale, NJ: Erlbaum.

57. Roese, N. J. (1997). Counterfactual thinking. Psychological Bulletin, 121(1), 133-148.

58. Scherer, K. R. (1999). Appraisal theories. In: T. Dalgleish \& M. J. Power (Eds.). Handbook of Cognition and Emotion, (pp. 637-663). Chichester: Wiley.

59. Schoefer, K. (2008). The role of cognition and affect in the formation of customer satisfaction judgements concerning service recovery encounters. Journal of Consumer Behaviour, 7(3), 210-221.

60. Schoefer, K., \& Diamantopoulos, A. (2008). The role of emotions in translating perceptions of (in) justice into postcomplaint behavioral responses. Journal of Service Research, 11(1), 91-103.

61. Schoefer, K., \& Ennew, C. (2005). The impact of perceived justice on consumers' emotional responses to service complaint experiences. Journal of Services Marketing, 19(5), 261-270.

62. Silber, I., Israeli, A., Bustin, A., \& Ben Zvi, O. (2009). Recovery Strategies for Service Failures: The Case of Restaurants. Journal of Hospitality Marketing \& Management, 18(7), 730-740.

63. Smith, A. K., \& Bolton, R. N. (2002). The effect of customers' emotional responses to service failures on their recovery effort evaluations and satisfaction judgments. Journal of the Academy of Marketing Science, 30(1), 5-23.

64. Smith, A. K., Bolton, R. N., \& Wagner, J. (1999). A model of customer satisfaction with service encounters involving failure and recovery. Journal of Marketing Research, 36(3), 356-372.

65. Smith, C. A., \& Lazarus, R. S. (1993). Appraisal components, core relational themes, and the emotions. Cognition \& Emotion, 7(3/4), 233-269. 
66. Szymanski, D. M., \& Henard, D. H. (2001). Customer satisfaction: A meta-analysis of the empirical evidence. Journal of the Academy of Marketing Science, 29(1), 16-35.

67. Tax, S. S., Brown, S. W., \& Chandrashekaran, M. (1998). Customer evaluations of service complaint experiences: Implications for relationship marketing. Journal of Marketing, 62(2), 60-76.

68. Tooby, J., \& Cosmides, L. (2008). The evolutionary psychology of the emotions and their relationship to internal regulatory variables. In: M. Lewis, J. M. Haviland-Jones \& L. F. Barrett (Eds.). Handbook of Emotions, (pp. 114-137). New York, NY: Guilford Press.

69. Tsai, W-C., \& Huang, Y-M. (2002). Mechanisms linking employee affective delivery and customer behavioral intentions. Journal of Applied Psychology, 87(5), 1001-1008.

70. Van Kleef, G. A. (2009). How emotions regulate social life: The emotions as social information (EASI) model. Current Directions in Psychological Science, 18(3), 184-188.

71. Van Kleef, G. A., Anastasopoulou, C., \& Nijstad, B. A. (2010a). Can expressions of anger enhance creativity? A test of the emotions as social information (EASI) model. Journal of Experimental Social Psychology, 46(6), 1042-1048.

72. Van Kleef, G. A., De Dreu, C. K. W., Manstead, A. S. R., \& Mark, P. Z. (2010b). An interpersonal approach to emotion in social decision making: The emotions as social information model. Advances in experimental social psychology. Academic Press, 45-96.

73. Verduyn, P., Van Mechelen, I., Tuerlinckx, F., Meers, K., \& Van Coillie, H. (2009). Intensity profiles of emotional experience over time. Cognition \& Emotion, 23(7), 1427-1443.

74. Walster, E., Berscheid, E., \& Walster, G. W. (1978). Equity Theory and Research. Boston, MA: Allyn \& Bacon.

75. Warden, A., Huang C., \& Wu, W. (2008). Restaurant service failure recoveries: Role expectations of customers. Journal of Hospitality Marketing \& Management, 16(1), 159-180.

76. Westbrook, R. A., \& Oliver, R. L. (1991). The dimensionality of consumption emotion patterns and consumer satisfaction. Journal of Consumer Research, 18(1), 84-91. 